\title{
Mineralogical analysis of the respiratory tract in aluminium oxide-exposed workers
}

\author{
C. Voisin*, F. Fisekci\$, B. Buclez+, A. Didier $¥$, B. Couste*, F. Bastien\$, \\ P. Brochard*†\#, J-C. Pairon*\$†\#
}

\begin{abstract}
Mineralogical analysis of the respiratory tract in aluminium oxide-exposed workers. $C$. Voisin, F. Fisekci, B. Buclez, A. Didier, B. Couste, F. Bastien, P. Brochard, J-C. Pairon. (C)ERS Journals Ltd 1996.

ABSTRACT: A retrospective study was conducted in order to characterize the retention of fibrous and nonfibrous mineral particles in the respiratory tract in subjects with previous occupational exposure in the aluminium industry.

Bronchoalveolar lavage (BAL) fluid (three samples) or lung parenchyma (two samples) were studied using analytical transmission electron microscopy in five patients.

A high concentration of aluminium fibres $\left(>10^{7}\right.$ fibres ${ }^{-1}$ dry lung) was identified in two lung tissue samples, and aluminium fibres were also identified in BAL fluid in three patients. All fibres were short (mean length: 1-2 $\mu \mathrm{m}$ ), with no fibre longer than $5 \mu \mathrm{m}$. Some biopersistence of these fibres in the respiratory tract is suggested from these observations, since fibres were identified in biological samples collected more than 4 yrs after cessation of exposure in four out of five patients.

Occupational physicians should be aware of possible exposure to short, thin aluminium fibres during primary aluminium production. Further studies are needed to assess the potential health effects of these fibres. Industrial hygiene measurements should also be performed to document the potential sources of exposure to aluminium fibres in this industry.
\end{abstract}

Eur Respir J., 1996, 9, 1874-1879.
*Laboratoire d'Etude des Particules Inhalées, Paris, France. \$Service de Pneumologie et de Pathologie Professionnelle, CHI Créteil, France. ${ }^{+}$Aluminium Pechiney, Gardanne, France. ${ }^{\ddagger}$ Service de Pneumologie, CHU Rangueil, Toulouse, France. †INSERM Unité 139, Créteil, France. \#Institut Interuniversitaire de Médecine du Travail de Paris Ile de France, Paris, France

Correspondence: J-C. Pairon

Service de Pneumologie et de Pathologie professionnelle

CHI Créteil

40 avenue de Verdun

94010 Créteil Cedex

France

Keywords: Aluminium oxide fibres

asbestos bodies

asbestos fibres

nonfibrous mineral particles

transmission electron microscopy

Received: October 191995

Accepted after revision May 221996
Evidence concerning a relationship between work in the aluminium industry and lung disease has been documented by several studies [1-4]. Respiratory investigations have concentrated on four diseases: asthma syndrome, chronic obstructive lung disease, lung cancer and pulmonary fibrosis [5]. However, other diseases have also been reported, such as granulomatosis, desquamative interstitial pneumonia and alveolar proteinosis [6-8]. Case series on aluminium potroom workers have identified an asthma-like syndrome, that appears to be due to an irritative rather than an allergic mechanism. However, it is not possible to conclude whether potroom exposure initiates asthma or precipitates asthma-like symptoms in a predisposed individual [1]. The investigation of the relationship between work in an aluminium smelter and respiratory symptoms or lung function impairment suggestive of obstructive lung disease, taking into account tobacco smoking, has been documented by some crosssectional studies $[2,9]$. It was concluded that impaired lung function was observed in aluminium smelter workers compared to unexposed control subjects. Some recent studies have concluded that a true aluminium potroom asthma exists [10,11]. Although a close relationship has been reported between the levels of fluoride exposure and work-related asthma symptoms, there are also some arguments to suggest a hypersensitivity reaction $[10,11]$. According to experts from the International Agency for
Research on Cancer, despite the wide scatter of the results of epidemiological studies, there is sufficient evidence to suggest that certain exposures occurring during aluminium production can cause lung cancer in humans [12, 13]. In epidemiological studies, pitch volatiles have been fairly consistently suggested as possible causative agents. Finally, a few case reports of pulmonary fibrosis occurring in workers exposed to aluminium dust in the aluminium industry or other industrial sectors have also been published [3, 14-17].

Mineralogical analysis of bronchoalveolar lavage (BAL) fluid or lung tissue provides an estimate of past exposure to insoluble particles. Fibrous and nonfibrous mineral particles (NFMP) may be counted by conventional light microscopy (quantification of asbestos bodies) and analytical transmission electron microscopy (ATEM) [18-20]. This evaluation of the retention of mineral particles in the lung has been shown to provide invaluable assistance in some respiratory diseases, mainly asbestos-related diseases, allowing the establishment of a dose-response relationship between lung cancer or parenchymal fibrosis and the number of asbestos bodies in BAL fluid or lung tissue $[21,22]$. However, this type of mineralogical analysis has rarely been performed in aluminium industry workers $[14,16]$.

We report the lung retention of fibrous particles and NFMP as evaluated by ATEM in five subjects who had 
worked in the aluminium industry and whose aluminium fibres (fibres containing only aluminium on chemical microanalysis) were identified in BAL fluid or lung tissue.

\section{Patients and methods}

\section{Patients}

The subjects included were those for whom a mineralogical analysis of BAL fluid or lung tissue samples using ATEM had been requested in our laboratory between 1990 and 1993, and for whom industrial exposure to aluminium minerals was evident on the basis of the occupational questionnaire. Five patients were identified on the basis of these criteria. For each patient, information was collected about tobacco smoking, presumed diagnosis at the time of request for analysis of the samples, and job history, including dates of beginning and end of each occupation.

Patient No. 1. A nonsmoking 55 year old man, who had worked for $30 \mathrm{yrs}$ in the primary aluminium industry (3 yrs as potline operator with the Söderberg process and 27 yrs as a casthouse operator), was investigated. Pulmonary function tests (spirometry) showed a restrictive syndrome (total lung capacity (TLC) 53\% of predicted value). An impairment of carbon monoxide transfer was also noted. The patient had stopped working 4 yrs before undergoing surgery. Histological analysis of a lung biopsy specimen led to the diagnosis of diffuse interstitial fibrosis.

Patient No. 2. A nonsmoking 55 year old man, who had a 28 year history of working in the aluminium smelting industry (Söderberg process), was sent to the emergency unit of a Chest Department with massive haemoptysis. Pneumonectomy was performed and the diagnosis of pseudoneoplastic pulmonary amyloidosis was established. He had stopped working 5 yrs before collection of the lung tissue sample.

Patient No. 3. A nonsmoking 72 year old man, who had a 31 year history of working in an alumina plant (bauxite attack by chemical process), was found to have diffuse interstitial fibrosis on high resolution computed tomography (HRCT). Pulmonary function tests (spirometry) showed a restrictive syndrome (TLC 50\% pred). An impairment of carbon monoxide transfer was also noted. The patient had stopped working $10 \mathrm{yrs}$ before collection of BAL fluid.

Patient No. 4. A 26 year-old man, who had a 6 month history of working in the aluminium smelting industry as a crushed bath operator, was investigated for dyspnoea at work. He was found to have bronchial hyperresponsiveness confirmed by pulmonary function tests. He stopped working 6 months before collection of the biological sample (BAL fluid). He was a smoker with a cumulative tobacco consumption of 10 pack-yrs.

Patient No. 5. A 68 year old man, who was an ex-smoker (30 pack-yrs) and had worked for 9 yrs sorting scoria derived from an aluminium foundry and 16 yrs sorting various metals, was investigated for dyspnoea and crackles.
Chest radiograph and computed tomography (CT) scan showed interstitial opacities. Pulmonary function tests (spirometry) showed a mild restrictive impairment (TLC $79 \%$ pred) with no influence on carbon monoxide transfer. The patient had stopped working 2 yrs before collection of the BAL fluid sample.

\section{Particle analysis}

Preparation and mineralogical analysis of samples were performed as described previously [20-22]. Briefly, BAL fluid or lung tissue samples were collected in flasks containing $10 \mathrm{~mL}$ of $10 \%$ formalin. Samples were allowed to react at room temperature for $2 \mathrm{~h}$ with freshly filtered sodium hypochlorite until all organic material had been digested. The suspension was then filtered through a membrane filter (Millipore $25 \mathrm{~mm}, 3 \mu \mathrm{m}$ pore size) or a carbon-coated polycarbonate membrane (Nuclepore, $0.4 \mu \mathrm{m}$ pore size) for light microscopic and electron microscopic analysis, respectively. Two samples were analysed for each patient. The first sample allowed quantification of asbestos bodies in the BAL fluid or in dry lung tissue by conventional light microscopy. The second sample was analysed using a transmission and scanning electron microscope (ATEM SCAN JEOL EX II) fitted with an energy dispersive X-ray spectrometer (TRACOR TN 5502). Briefly, three variables were determined for the second sample. Firstly, the numerical concentration of all types of NFMP, expressed per millilitre of BAL fluid or per gram of dry lung tissue, and the relative percentage of different mineralogical species obtained from the analysis of 50 particles in randomly selected fields were determined. Each particle was identified by morphological features, electron diffraction pattern and microanalysis spectrum (allowing detection of elements with atomic number greater than 10). The X-ray spectrum of aluminium shows a major K $\alpha$ peak at 1,487 eV. Particles containing aluminium were counted regardless of the other associated mineralogical species. As the relative concentration of a given mineralogical species does not reflect total lung load for this mineral, the absolute concentration of particles containing aluminium was calculated for each subject. This variable was obtained both for BAL fluid samples and lung tissue samples as follows: absolute aluminium concentration=total numerical concentration of all particles (per $\mathrm{mL}$ of BAL fluid or per gram of dry lung tissue) $\times$ percentage of particles containing aluminium (in BAL fluid or lung tissue). This variable was considered to be a good estimate of the load of aluminium-containing particles in the lung. Secondly, the numerical concentration of fibrous mineral particles containing only aluminium (hereafter referred to as "aluminium fibres") expressed per millilitre of BAL fluid or per gram of dry lung tissue, and their granulometry (length, diameter, and length/diameter ratio) were determined. No distinction was made between $\alpha$ and $\gamma$ alumina. Thirdly, the numerical concentration of other fibrous particles, especially asbestos fibres was measured.

\section{Results}

Results of the mineralogical analysis in the five patients are presented in Table 1. All but one of the patients had 
Table 1. - Results of mineralogical analysis of BAL fluid samples and lung tissue samples

\begin{tabular}{|c|c|c|c|c|c|}
\hline \multirow{2}{*}{$\begin{array}{l}\text { Case } \\
\text { No. }\end{array}$} & \multirow{2}{*}{$\begin{array}{l}\text { Biological } \\
\text { sample }\end{array}$} & \multirow{2}{*}{$\begin{array}{l}\text { Time since } \\
\text { cessation of } \\
\text { exposure }\end{array}$} & \multirow{2}{*}{$\begin{array}{l}\text { LM analysis } \\
\text { AB count* } \\
\text { AB } \cdot \mathrm{g}^{-1}\end{array}$} & \multicolumn{2}{|c|}{ TEM analysis } \\
\hline & & & & NFMP & Aluminium fibres \\
\hline 1 & $\begin{array}{l}\text { Lung } \\
\text { tissue }\end{array}$ & $4 \mathrm{yrs}$ & 142 & $\begin{array}{l}8.5 \times 10^{9} \mathrm{p} \cdot \mathrm{g}^{-1} \\
(40 \% \mathrm{Al}) \\
3.4 \times 10^{9} \mathrm{p} \mathrm{Al} \cdot \mathrm{g}^{-1}\end{array}$ & $\begin{array}{l}2.9 \times 10^{7} \text { fibres } \cdot \mathrm{g}^{-1} \\
\text { Diameter }(\mu \mathrm{m}): 77 \% \leq 0.05 ; \\
9 \% 0.2-0.4 ; 12 \% 0.4-0.6 ; 2 \% 0.6-0.8 \\
\text { Length }(\mu \mathrm{m}): 2.3 \pm 1.4 \\
\text { Ratio (length/diameter): } 25.6 \pm 20.3\end{array}$ \\
\hline 2 & $\begin{array}{l}\text { Lung } \\
\text { tissue }\end{array}$ & 5 yrs & $<40$ & $\begin{array}{l}6.4 \times 10^{9} \mathrm{p} \cdot \mathrm{g}^{-1} \\
(56 \% \mathrm{Al}) \\
3.58 \times 10^{9} \mathrm{p} \mathrm{Al} \cdot \mathrm{g}^{-1}\end{array}$ & $\begin{array}{l}5.2 \times 10^{7} \text { fibres } \cdot \mathrm{g}^{-1} \\
\text { Diameter }(\mu \mathrm{m}): 16 \% \leq 0.05 \\
22 \% 0.05-0.1 ; 46 \% 0.1-0.2 \\
12 \% 0.2-0.4 ; 4 \% 0.4-0.6 \\
\text { Length }(\mu \mathrm{m}): 1.4 \pm 0.8 \\
\text { Ratio (length/diameter): } 13.2 \pm 8.6\end{array}$ \\
\hline 3 & $\begin{array}{l}\text { BAL } \\
\text { fluid }\end{array}$ & $10 \mathrm{yrs}$ & NP & $\begin{array}{l}1.6 \times 10^{5} \mathrm{p} \cdot \mathrm{mL}^{-1} \\
(7 \% \mathrm{Al}) \\
1.12 \times 10^{4} \mathrm{p} \mathrm{Al} \cdot \mathrm{mL}^{-1}\end{array}$ & $\begin{array}{l}3 \times 10^{2} \text { fibres } \cdot \mathrm{mL}^{-1} \\
\text { Granulometry not performed } * *\end{array}$ \\
\hline 4 & $\begin{array}{l}\text { BAL } \\
\text { fluid }\end{array}$ & $6 \mathrm{mo}$ & ND & $\begin{array}{l}4.5 \times 10^{5} \mathrm{p} \cdot \mathrm{mL}^{-1} \\
(20 \% \mathrm{Al}) \\
0.9 \times 10^{5} \mathrm{p} \mathrm{Al} \cdot \mathrm{mL}^{-1}\end{array}$ & $\begin{array}{l}9.6 \times 10^{3} \text { fibres } \cdot \mathrm{mL}^{-1} \\
\text { Diameter }(\mu \mathrm{m}): 68 \% \leq 0.05 \\
18 \% 0.05-0.1 ; 14 \% 0.1-0.2 \\
\text { Length }(\mu \mathrm{m}): 0.72 \pm 0.4 \\
\text { Ratio (length/diameter): } 20.3 \pm 9.5\end{array}$ \\
\hline 5 & $\begin{array}{l}\text { BAL } \\
\text { fluid }\end{array}$ & $18 \mathrm{yrs}$ & ND & $\begin{array}{l}8.6 \times 10^{5} \mathrm{p} \cdot \mathrm{mL}^{-1} \\
(15 \% \mathrm{Al}) \\
1.29 \times 10^{5} \mathrm{p} \mathrm{Al} \cdot \mathrm{mL}^{-1}\end{array}$ & $\begin{array}{l}2.1 \times 10^{4} \text { fibres } \cdot \mathrm{mL}^{-1} \\
\text { Diameter }(\mu \mathrm{m}): 11 \% \leq 0.05 \\
46 \% 0.05-0.1 \\
43 \% 0.1-0.2 \\
\text { Length }(\mu \mathrm{m}): 0.79 \pm 0.4 \\
\text { Ratio (length/diameter): } 8.6 \pm 4.9\end{array}$ \\
\hline
\end{tabular}

The AB count was determined by light microscopy (LM). Analysis of nonfibrous particles was performed by transmission electron microscopy (TEM). Quantification of aluminium fibres and distribution of diameter and length of aluminium fibres were assessed by TEM. All results are expressed per gram of dry lung tissue for lung tissue samples. NFMP: non-fibrous mineral particles; BAL: bronchoalveolar lavage; AB: asbestos bodies; p: particles; Al: aluminium; NP: not performed; ND: not determined. *: Limit of detection of the method used in the laboratory for the quantification of $\mathrm{AB}$ was $40 \mathrm{AB} \cdot \mathrm{g}^{-1}$ of dry lung tissue; a significant lung retention of $\mathrm{AB}$ was considered to be greater than $1,000 \mathrm{AB} \cdot \mathrm{g}^{-1}$ of dry lung tissue; **: due to a very low number of fibres observed, granulometry was not performed.

ceased exposure to aluminium products for at least 4 yrs before collection of the biological sample. No significant retention of asbestos bodies was observed in the four cases in which this retention was studied by light microscopic analysis. No case exhibited significant concentration of asbestos fibres in BAL fluid or lung tissue using ATEM. A high concentration of nonfibrous mineral particles was observed in the lung tissue samples analysed, with a high percentage of particles containing aluminium (40 and 56\% in case No. 1 and 2, respectively).

The most striking observation was obtained from TEM analysis of aluminium fibres: the fibres were rather short and thin, with a mean length of about 1-2 $\mu \mathrm{m}$ and no fibres longer than $5 \mu \mathrm{m}$. The mean length: diameter ratio of aluminium fibres ranged 8.6-25.6. Elementary chemical analysis with energy dispersive spectrometry (EDS) revealed the presence of aluminium with no other associated elements (fig. 1). The electron diffraction pattern showed that the fibres were crystalline.

No other fibres were observed in lung tissue samples of cases No. 1 and 2, whilst a low concentration of chrysotile fibres was identified in BAL fluid samples of cases Nos. 3, 4 and $5\left(6 \times 10^{2}, 9 \times 10^{2}\right.$ and $1.7 \times 10^{3}$ fibres. $\mathrm{mL}^{-1}$ in cases No. 3, 4 and 5, respectively).

\section{Discussion}

The uses of aluminium are dictated by its chemical and physical properties, which include low specific gravity, high tensile strength, ductility, malleability, corrosion resistance and high electrical conductivity. It is widely used in construction, transportation, transmission of electricity, machinery, equipment and packaging [12, 23, 24]. The potential sources of respiratory pollutants and the processes involved in the aluminium primary industry (concerning patients Nos. 1-4 in our series) have been described previously [23-25], and reviewed by Kongerud et al. [11].

The nature and level of contaminants and other agents in the potroom may be influenced by the type of pot (prebake or Söderberg), building ventilation, size of operation, and electric current used [12, 23]. However, some of these substances have been identified, e.g. alumina, aluminium fluoride, particles of aluminium metal, carbon monoxide, chlorine, coke, cryolite, fluorides, oil mists, hydrogen fluoride, pitch, petroleum, polynuclear aromatic compounds, sulphur dioxide and possibly asbestos. Whilst there may be skin contact with various materials, the main route of exposure is inhalation. 
a)

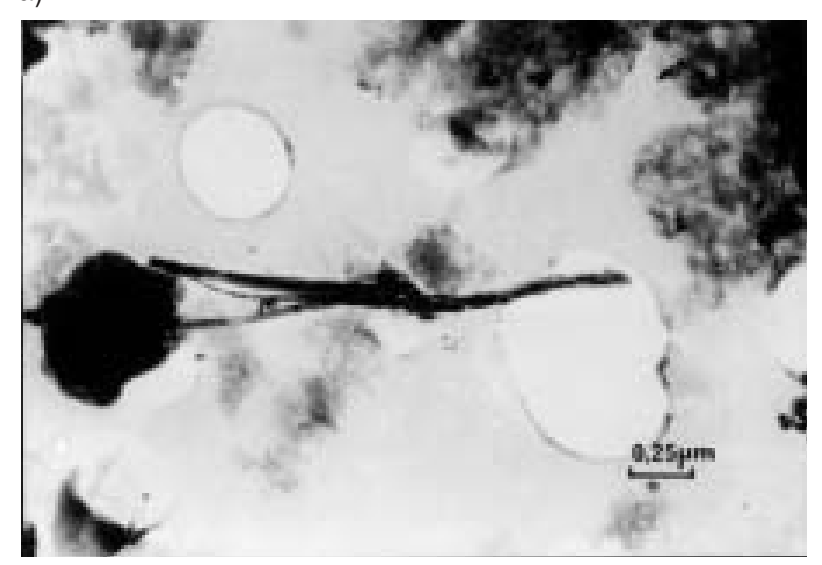

b)

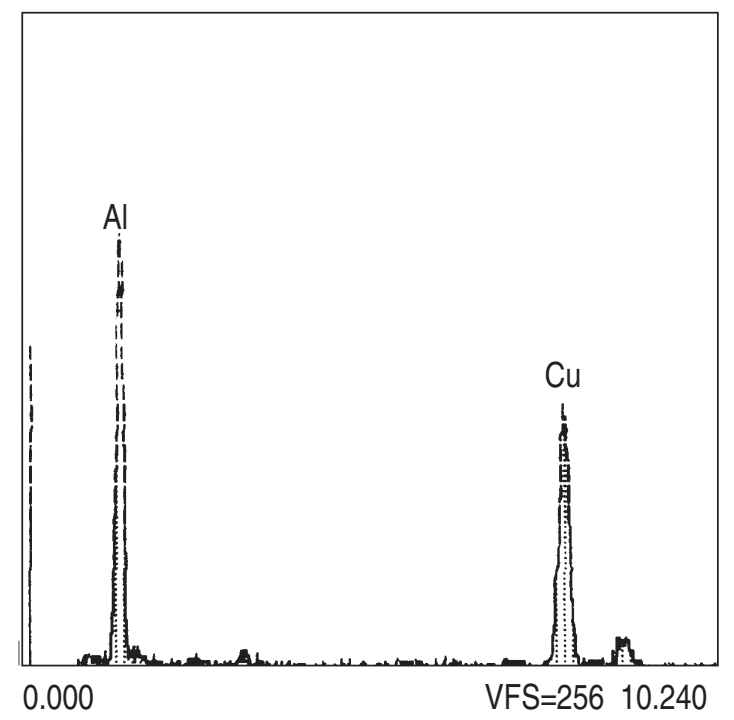

C)

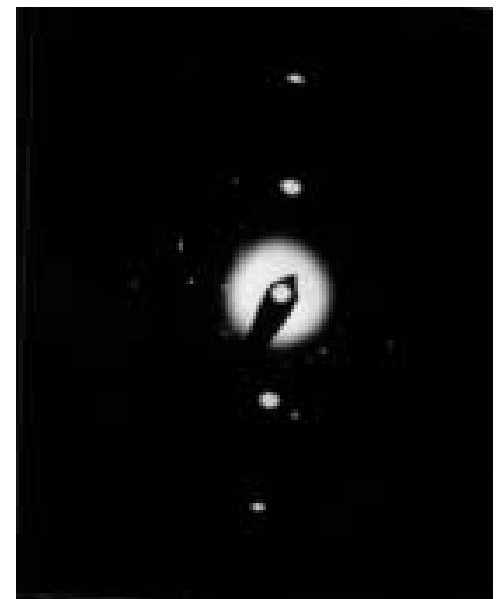

Fig. 1. - Morphological features of aluminium fibres in lung tissue on analytical transmission electron microscopy (ATEM). Characterization of the fibre was based on: a) morphological features; b) typical X-ray energy dispersive spectrum; and c) selected area electron diffraction. Energy location of significantly detected peaks: $\mathrm{Al}(\mathrm{K} \alpha) 1.49 \mathrm{keV}, \mathrm{Cu}(\mathrm{K} \alpha, \mathrm{K} \beta) 8.04$ $\mathrm{keV}, 8.90 \mathrm{keV}$ The $\mathrm{Al}$ peak was attributed to the fibres, $\mathrm{Cu}$ from the grid and apparatus. No peak was observed for $\mathrm{Na}$

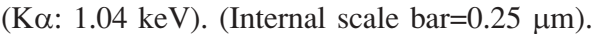

To our knowledge, aluminium fibres are not added at any steps of the process. However, the presence of aluminium fibres in the air of potrooms during primary aluminium production has been reported [26]. One author mentioned the presence of short (mean length $0.87 \mu \mathrm{m}$ ) and thin (mean diameter $0.05 \mu \mathrm{m}$ ) fibres in the work environment in this industry [26]. Energy dispersive Xray microanalysis revealed that only sodium and aluminium elements were detected. These fibres were, therefore, assumed to be sodium aluminium tetrafluoride fibres. The author suggested that these fibres were produced during recrystallization of fumes from the electrolyte [26].

While aluminium is commonly encountered when analysing mineral particles in BAL fluid or lung tissue, the presence of this mineral in a fibrous form in human lungs has been poorly documented [14]. GILKS and CHuRG reported a high concentration of aluminium fibres in the lung tissue of a patient with lung fibrosis [14]. They demonstrated these fibres consisted of $\alpha$-aluminium oxide. They also reported a mean concentration of $7 \times 10^{5}$ aluminium fibres per gram of dry lung in nine reference cases. In our experience, in subjects without any significant occupational exposure to mineral particles (either fibrous particle or NFMP), lung concentration of aluminium fibres was always less than $3.5 \times 10^{5}$ fibres per gram of dry lung tissue (five patients; range of NFMP concentration $0.22 \times 10^{9}$ to $0.38 \times 10^{9}$ particles $\cdot \mathrm{g}^{-1}$ with percentage of aluminium-containing particles less than $2 \%$; range of all fibres concentration: $3.4 \times 10^{6}$ to $5.7 \times 10^{6}$ fibres.g- ${ }^{-1}$; range of mean length of fibres: 0.5 to $0.8 \mu \mathrm{m}$; fibres were identified as mullite and chrysotile fibres) (Voisin et al., unpublished data). In BAL fluid, no aluminium fibres were detected (three patients; range of NFMP concentration $0.079 \times 10^{6}$ to $0.12 \times 10^{6}$ particles $\cdot \mathrm{mL}^{-1}$ with percentage of aluminium-containing particles less than $8 \%$; range of all fibres concentration: $0.25 \times 10^{3}$ to $0.5 \times 10^{3}$ fibres. $\mathrm{mL}^{-1}$; range of mean length of fibres 0.65 to $0.8 \mu \mathrm{m}$; fibres were identified as chrysotile fibres). These data are consistent with those reported by Gilks and Churg [14].

In the present series, all five subjects employed in the aluminium industry (four in the primary industry) exhibited levels of aluminium fibre retention much higher than those observed in control subjects. The exact nature of these fibres could not be established but they were different from the short mullite fibres, which are commonly encountered in BAL fluid and lung tissue and are not considered pathogenic to humans [27]. Some elements (such as oxygen, hydrogen or fluorine) could be present in aluminium-containing fibres in these subjects, but our analytical system was unable to detect these elements (as their atomic numbers are all less than 10). However, elemental chemical analysis with EDS also failed to reveal the presence of sodium. We cannot, therefore, confirm that the chemical composition of aluminium-containing fibres was similar to that described by GYLSETH et al. [26], unless sodium was leached in the biological fluid of the respiratory tract. Alternatively, our data are also consistent with various forms of aluminium oxides (such as alumina trihydroxide $\mathrm{Al}(\mathrm{OH})_{3}$ or crystallized alumina $\mathrm{Al}_{2} \mathrm{O}_{3}$, either $\alpha$ or $\gamma$ form). As the fibre parameters are similar to those reported by GILKS and CHURG [14], we consider that the most probable fibre composition was 
$\mathrm{Al}_{2} \mathrm{O}_{3}$. Industrial hygiene measurements should be performed to document the presence of aluminium fibres during the various steps of alumina synthesis.

The concentrations of aluminium nonfibrous particles were also high in these five subjects, largely above mean or median values reported for aluminium-containing NFMP in BAL fluid samples or lung tissue samples of controls in previous series analysed in the same laboratory $[18,19]$. The mean value of aluminium-containing NFMP in BAL fluid was $5.6 \times 10^{3}$ particles $\cdot \mathrm{mL}^{-1}$ (range $0-1.28 \times 10^{4}$ particles $\cdot \mathrm{mL}^{-1}$ ) in the first series of 42 controls [19]. Mean values of aluminium-containing NFMP in BAL fluid and lung tissue were $1 \times 10^{4}$ particles. $\mathrm{g}^{-1}$ dry lung tissue in the second series of 10 patients without any known recent occupational exposure to mineral particles [18]. The potential pathogenetic role of this high level of aluminium-containing NPMP in the respiratory tract remains open to question.

Only a few cases of parenchymal fibrosis in primary aluminium industry workers have been reported in the recent literature $[14,16]$. Older and more controversial data dealing with the fibrogenic potency of aluminium dust were discussed by WALDRON [28]. However, in a recent experimental study in rats, using intratracheal instillation of various alumina samples, the fibrogenic potency of a chemical-grade alumina sample (different from industrial aluminas) was demonstrated [29]. In contrast, no fibrosis was noted with five other alumina samples used in aluminium production. This was consistent with the results of ToRNLING et al. [30], who found no histological signs of fibrosis in any of the animals instilled intratracheally with alumina dust, either with or without adsorbed fluorides. However, fibronectin concentrations were significantly increased in BAL fluid 1 year after exposure in animals treated with both alumina dust samples. Data concerning the potential role of aluminium fibres in the development of lung fibrosis in humans are limited to case reports from GILKS and CHURG [14] and cases Nos. 1 and 3 in the present series. Although no other aetiological factor (particularly asbestos) could be identified in these cases, no definite conclusions can be reached. All aluminium fibres were rather short, measuring less than $5 \mu \mathrm{m}$ in all of the documented cases. This is generally considered to be an argument against a fibrogenic potency for a given fibre, independently of its chemical composition [31]. In contrast, it is important to emphasize that, in the present series, the latency since cessation of exposure ranged from 6 months to $18 \mathrm{yrs}$, indicating that these aluminium fibres exhibit a certain biopersistence in man. Biopersistence has been shown to be an important parameter in the lung pathogenicity of minerals [32].

In conclusion, this series revealed a significant retention of aluminium fibres in biological samples from subjects working in the aluminium industry. In some subjects, these aluminium fibres remained in the respiratory tract for many years after cessation of exposure suggesting biopersistence of this mineral. The role of these short fibres in the development of parenchymal disease remains open to question and should be documented by further investigations, which should also include industrial hygiene measurements of aluminium particles in the potroom atmosphere at different steps of the process, with determination of granulometric parameters.
Acknowledgements: The authors are indebted to M.A. Billon-Galland, P. Grall and X. Janson (Laboratoire d'Etude des Particules Inhalées, Paris, France) for excellent technical assistance, and to P Personnet (LRF, Aluminium Pechiney, St Jean de Maurienne, France) for helpful comments about the industrial process. They are also indebted to Y. Aniel (Aiguelongue, France), F. Capron (Hôtel Dieu, Paris, France), P. Chanez (Montpellier, France), M. Dahan (Toulouse, France), B. Fourquet (Calais, France), M.C. Guilbert (Aluminium Dunkerque, Loon Plage, France), C. Jambon (Montpellier, France), Y. Laborde (Pau, France), D. Ledaguenel (Bordeaux, France), P. Leophonte (Toulouse, France), F.B. Michel (Montpellier, France), G. Mignonat (Pau, France), G. Newinger (Mulhouse, France), F. Pellerin (Montpellier, France), D. Robinet (Saint Louis, France), S. Voisin-Saltiel (Corbeil, France) for providing biological samples and clinical information.

\section{References}

1. Abramson MJ, Wlodarczyk JH, Saunders NA, Hensley MJ. Does aluminum smelting cause lung disease? Am Rev Respir Dis 1989; 139: 1042-1057.

2. Chan-Yeung M, Wong R, MacLean L, et al. Epidemiologic health study of workers in an aluminum smelter in British Columbia. Am Rev Respir Dis 1983; 127: 465-469.

3. Gaffuri E, Donna A, Pietra R, Sabbioni E. Pulmonary changes and the aluminum levels following inhalation of alumina dust: a study on four exposed workers. Med Lav 1985; 76: 222-227.

4. Kongerud J, Gronnesby JK, Magnus P. Respiratory symptoms and lung function of aluminium potroom workers. Scand J Work Environ Health 1985; 16: 270-277.

5. Kongerud J, Samuelsen SO. A longitudinal study of respiratory symptoms in aluminum potroom workers. $\mathrm{Am}$ Rev Respir Dis 1991; 144: 10-16.

6. De Vuyst P, Dumortier P, Schandené L, Estenne M, Verhest A, Yernault JC. Sarcoid-like lung granulomatosis induced by aluminum dusts. Am Rev Respir Dis 1987; 135: 493-497.

7. Herbert A, Sterling G, Abraham J, Corrin B. Desquamative interstitial pneumonia in an aluminum welder. Hum Pathol 1982; 13: 694-699.

8. Miller RR, Churg AM, Hutcheon M, Lam S. Pulmonary alveolar proteinosis and aluminum dust exposure. Am Rev Respir Dis 1984; 130: 312-315.

9. Townsend MC, Enterline PE, Sussman NB, Bonney TB, Rippey LL. Pulmonary function in relation to total dust exposure at a bauxite refinery and alumina-based chemical products plant. Am Rev Respir Dis 1985; 132: 1174 1180 .

10. Kongerud J, Soyseth V, Burge S. Serial measurements of peak expiratory flow and responsiveness to methacholine in the diagnosis of aluminium potroom asthma. Thorax 1992; 47: 292-297.

11. Kongerud J, Boe J, Soyseth V, Naalsund A, Magnus P. Aluminium potroom asthma: the Norwegian experience. Eur Respir J 1994; 7: 165-172.

12. International Agency for Research on Cancer. IARC monographs on the evaluation of carcinogenic risks to humans: polynuclear aromatic compounds. Part 3. Industrial exposures in aluminum production, coal gasification, coke production, and iron and steel founding. Lyon, France. 1984; 34: 1-220.

13. International Agency for Research on Cancer. IARC monographs on the evaluation of carcinogenic risks to humans: overall evaluations of carcinogenicity. An updating of IARC monographs volumes 1-42. Lyon, France. 1987; Suppl. 7: 89-91. 
14. Gilks B, Churg A. Aluminum-induced pulmonary fibrosis: do fibers play a role? Am Rev Respir Dis 1987; 136: 176-179.

15. De Vuyst P, Dumortier P, Rickaert F, Van de Weyer R, Lenclud C, Yernault JC. Occupational lung fibrosis in an aluminum polisher. Eur J Respir Dis 1986; 68: 131140.

16. Jederlinic PJ, Abraham JL, Churg A, Himmelstein JS, Epler GR, Gaensler EA. Pulmonary fibrosis in aluminum oxide workers. Am Rev Respir Dis 1990; 142: 1179 1184.

17. Vallyathan V, Bergeron WN, Robichaux PA, Craighead JE. Pulmonary fibrosis in an aluminum arc welder. Chest 1982; 81: 372-374.

18. Chariot P, Couste B, Guillon F, Gaudichet A, Bignon J, Brochard P. Nonfibrous mineral particles in bronchoalveolar lavage fluid and lung parenchyma from the general population. Am Rev Respir Dis 1992; 146: 61-65.

19. Pairon JC, Billon-Galland MA, Iwatsubo Y, et al. Biopersistence of nonfibrous mineral particles in the respiratory tract of subjects following occupational exposure. Environ Health Perspect 1994; 102 (Suppl. 5): 269 275.

20. Sebastien P, Billon MA, Janson X, Bonnaud G, Bignon $\mathrm{J}$. Utilisation du microscope électronique à transmission (MET) pour la mesure des contaminations par l'amiante. Arch Mal Prof 1978; 39: 229-248.

21. Roggli VL. Human disease consequences of fiber exposures: a review of human lung pathology and fiber burden data. Environ Health Perspect 1990; 88: 295-303.

22. Roggli VL, Pratt PC, Brody AR. Analysis of tissue mineral fiber content. In: Roggli VL, Greenberg SD, Pratt PC, eds. Pathology of Asbestos-associated Diseases. Boston, Little, Brown and Co., 1993; pp. 299-344.
23. Buclez B, Pellet F. Aluminium: EMC toxicologie, pathologie professionnelle. 1994; 16-002-A-10, 4p.

24. International Primary Aluminum Institute. Health committee review. The measurement of employee exposures in aluminum reduction plants. Chemical exposures. 2nd edn. London, IPAI Eds, 1991; 1-52.

25. Castel B. Les alumines et leurs applications. Paris, Nathan Eds, 1990; pp. 1-74.

26. Gylseth B, Bjorseth O, Dugstad O, Gjonses J. Occurrence of fibrous sodium aluminum tetrafluoride particles in potrooms of the primary aluminum industry. Scand $J$ Work Environ Health 1984; 10: 189-195.

27. Johnson NF, Haslam PL, Dewar A, Newman-Taylor AJ, Turner-Warwick M. Identification of inorganic dust particles in bronchoalveolar lavage macrophages by energy dispersive X-ray microanalysis. Arch Environ Health 1986; 41: 133-144.

28. Waldron HA. Non-neoplastic disorders due to metallic, chemical and physical agents. In: Parkes WR, ed. Occupational lung disorders. 3rd edn. Oxford, Butterworth Heinemann, 1994; pp. 593-643.

29. Ess SM, Steinegger AF, Ess HJ, Schlatter C. Experimental study on the fibrogenic properties of different types of alumina. Am Ind Hyg Assoc J 1993; 54: 360-370.

30. Tornling G, Blaschke E, Eklund A. Long-term effects of alumina on components of bronchoalveolar lavage fluid from rats. $\mathrm{Br}$ J Ind Med 1993; 50: 172-175.

31. Lippman M. Biophysical factors affecting fiber toxicity. In: Warheit DB, ed. Fiber Toxicology. San Diego, Academic Press Inc., 1993; pp. 259-304.

32. Bignon J, Saracci R, Touray JC. Biopersistence of respirable synthetic fibres and minerals: a workshop, Lyon, France, 7-9 September 1992. Environ Health Persp 1994; 102 (Suppl. 5): 3-5. 